\title{
SIFAT FISIK, KIMIA, DAN ORGANOLEPTIK PADA PEMBUATAN DODOL YANG DISUBSTITUSI DENGAN WORTEL (Daucus carota, Linn) Basito $^{1}$ \\ ${ }^{1}$ Staf Pengajar Jurusan Teknologi Hasil Pertanian UNS
}

\begin{abstract}
ABSTRAK
Dodol merupakan makanan semi basah yang pembuatannya dari tepung beras ketan, santan kelapa, dan gula dengan atau tanpa penambahan bahan makanan dan bahan tambahan makanan lain yang diijinkan. Untuk memperbaiki nilai gizi pada dodol dapat dilakukan dengan menambah bahan - bahan lain sebagai sumber vitamin salah satunya adalah wortel. Umbi wortel mengandung karoten dalam jumlah yang tinggi, sehingga berpotensi sebagai sumber vitamin A. Penelitian ini bertujuan untuk mengetahui pengaruh substitusi wortel dalam pembuatan dodol terhadap sifat kimia, fisik dan organoleptik dodol.

Penelitian ini menggunakan Rancangan Acak Lengkap Faktorial dengan 3 kali ulangan. Ada 2 variabel dalam rancangan penelitian ini yaitu variabel tetap dan variabel tidak tetap. Variabel tetap dalam penelitian ini adalah variasi bentuk penambahan wortel (bubur wortel dan tepung wortel) dan variasi konsentrasi wortel dan tepung beras ketan $(40: 60,30: 70,20: 80$, dan 0:100 (kontrol)). Sedangkan variabel tidak tetap yang diamati adalah sifat kimia meliputi: kadar air, karoten dan sifat fisik meliputi: tekstur, serta sifat organoleptik (warna, aroma, rasa, tekstur, dan keseluruhan). Data yang diperoleh dianalisis dengan menggunakan Metode Univariate kemudian dilanjutkan dengan menggunakan Uji Duncan Multiple Range Test (DMRT) pada taraf signifikasi $5 \%$.

Dari hasil penelitian dapat disimpulkan bahwa substitusi wortel dalam bentuk bubur maupun tepung wortel pada pembuatan dodol dengan variasi konsentrasi wortel dan tepung ketan berpengaruh terhadap kadar air, karoten dan tekstur dodol yang dihasilkan. Pada uji organoleptik menunjukkan bahwa dodol yang disukai adalah dodol dengan penambahan wortel dalam bentuk bubur wortel dengan konsentrasi bubur wortel dan tepung ketan 30:70. Dodol tersebut mengandung air 17,57\%, karoten 9,26 $\mu \mathrm{g} / \mathrm{g}$, dan memiliki tingkat kekerasan 2,24 N serta tingkat elastisitas $6,16 \mathrm{~mm}$.
\end{abstract}

Kata kunci: dodol, wortel, sifat kimia, sifat fisik, sifat organoleptik

ABSTRACT

Dodol is intermediate moisture food which is made from glutinous rice flour, coconut milk, and sugar with or without addition of other food and food additive. To improve nutritional value of dodol, it can added by other materials as source of vitamins like carrot. Carrot contains carotene in high number, so that is potential as source of vitamin A. This research aims to find out whether or not the carrot substitution in making of dodol affect the chemical, physical and organoleptic characterization of dodol produced.

This research applied Factorial Completely Randomized Design. There were 2 variables in this research design, fixed variables and dependent variables. Fixed variable in this research were various addition of carrot (carrot pasta and carrot flour) and various concentrations of carrot and glutinous rice flour (40:60, 30:70, 20:80, and 0:100 (control)). Dependent variables observed included chemical characteristic (water degree and carotenoid degree) and physical characteristic (texture and organoleptic characteristic: color, aroma, taste, texture, and overall). The data obtained then analyzed by using Univariate Method then continued by using Duncan Multiple Range Test (DMRT) at $5 \%$ of significant level.

The result of research show that substitution of carrot in the form of pasta and carrot flour at making of dodol with various concentrations of carrot and glutinous rice flour affect the water degree, carotenoid degree and texture of dodol produced. At organoleptic test indicated that dodol with addition of carrot pasta with concentration of carrot pasta and glutinous rice flour 30:70 is most appetite. The dodol containing 17,57\% of water, 9,26 $\mu \mathrm{g} / \mathrm{g}$ of carotenoid, and 2,24 $\mathrm{N}$ of hardness level and 6,16 $\mathrm{mm}$ of elasticity level.

Keyword: Dodol, carrot, chemical characteristic, physical characteristic, organoleptic characteristic.

\section{PENDAHULUAN}

Dodol merupakan makanan
tradisional, telah dikenal lama oleh
masyarakat Indonesia dan banyak diminati
oleh konsumen luar negeri. Hal tersebut
ditunjukkan oleh permintaan eksport dodol
untuk berbagai negara seperti Malaysia,
Singapura, Brunei dan Belanda (Anonim,
1993, dalam Asih Nurhayati, 1999). Dodol

merupakan salah satu produk olahan hasil pertanian yang diperkirakan mampu bersaing di pasar global. Prospek pemasaran dodol cukup cerah karena produk olahan ini banyak diminati masyarakat dari berbagai kalangan, hal ini terbukti dengan terdapatnya dodol di berbagai daerah, dan tetap berkembangnya produk - produk dodol di setiap daerah tersebut (Anonim, 2008). 
Secara umum bahan dasar pembuatan dodol adalah tepung ketan, gula kelapa dan santan kelapa, sehingga dodol mengandung karbohidrat, protein, dan lemak, namun sedikit mengandung vitamin. Saat ini jenis dan citarasa dodol makin banyak, diantaranya adalah dodol sirsak, nangka, durian, tape dan lainnya.

Usaha agar lebih lebih menarik konsumen terhadap dodol, dapat dilakukan dengan memberikan tambahan terhadap produk olahan tersebut yaitu salah satu cara yang dapat dilakukan adalah dengan memperbaiki nilai gizi yang dikandungnya. Salah satu bahan yang dapat digunakan sebagai bahan tambahan pada dodol dan merupakan sumber provitamin A alami sehingga dapat meningkatkan nilai gizi dodol adalah wortel (Daucus carota, L.). Menurut Ali dkk. (1994), wortel memiliki kandungan gizi yang banyak diperlukan oleh tubuh terutama sebagai sumber vitamin A. Umbi wortel banyak mengandung vitamin A yang disebabkan oleh tingginya kandungan karoten, yakni suatu senyawa kimia pembentuk vitamin A. Di samping beraktivitas sebagai provitamin A, karoten juga mempunyai aktivitas antioksidan yang secara umum dikenal untuk memberi perlindungan pada tubuh terhadap pengaruh negatif dari radikal bebas, menghambat pertumbuhan sel kanker, mencegah serangan jantung, mencegah katarak, meningkatkan fungsi kekebalan tubuh, mencegah penyakit kulit, dan lain- lain (Silalahi, 2006).

Dalam penelitian ini dibuat produk dodol dengan penambahan wortel sebagai sumber karoten, sebagai sumber provitamin A pada makanan sehari - hari, serta dapat diterima konsumen. Penambahan wortel dalam pembuatan dodol tentunya akan mempengaruhi tekstur, kadar air, karoten, dan sifat organoleptik dari dodol yang dihasilkan. Berdasarkan uraian tersebut, maka perlu dicari konsentrasi wortel dan tepung beras ketan yang tepat agar nantinya dodol yang dihasilkan dapat diterima konsumen.

\section{BAHAN DAN METODE}

\section{Bahan}

Bahan utama: santan kelapa $300 \mathrm{ml}$, gula kelapa 200 gr, dan perbandingan wortel dan tepung ketan 0: 100, 20:80, 30:70, 40:60. Sedangkan bahan kimia untuk Analisa karoten : petroleum eter, aseton, $\mathrm{Na}_{2} \mathrm{SO}_{4}$ anhidrous, dan aquades.

\section{Pembuatan Dodol}

Tahapan pembuatan dodol sebagaimana terlihat pada gambar 1

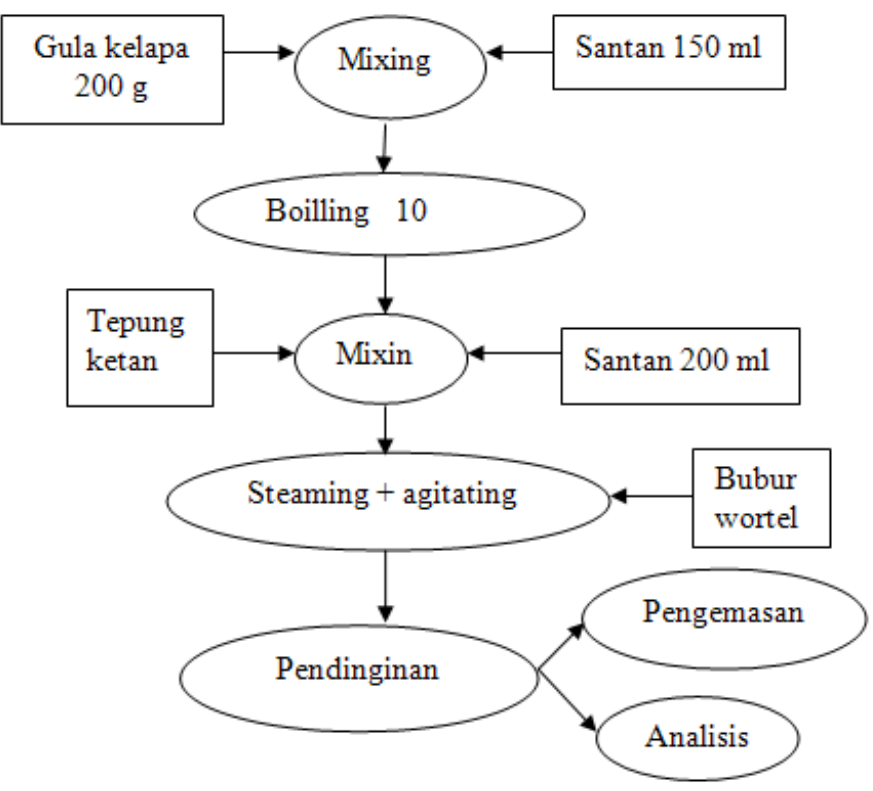

Gambar 1. Tahapan pembuatan dodol

Formulasi pembuatan dodol wortel

\begin{tabular}{|c|c|c|c|}
\hline Bahan Dasar & \multicolumn{3}{|c|}{ Perlakuan } \\
\cline { 2 - 4 } Dodol & W1R1 & W1R2 & W1R3 \\
\hline Santan & $300 \mathrm{ml}$ & $300 \mathrm{ml}$ & $300 \mathrm{ml}$ \\
\hline Gula kelapa & $200 \mathrm{gr}$ & $200 \mathrm{gr}$ & $200 \mathrm{gr}$ \\
\hline Tepung ketan & $60 \mathrm{gr}$ & $70 \mathrm{gr}$ & $80 \mathrm{gr}$ \\
\hline Bubur wortel & $40 \mathrm{gr}$ & $30 \mathrm{gr}$ & $20 \mathrm{gr}$ \\
\hline
\end{tabular}

\begin{tabular}{|c|c|c|c|}
\hline Bahan Dasar & \multicolumn{3}{|c|}{ Perlakuan } \\
\cline { 2 - 4 } Dodol & W2R1 & W2R2 & W2R3 \\
\hline Santan & $300 \mathrm{ml}$ & $300 \mathrm{ml}$ & $300 \mathrm{ml}$ \\
\hline Gula kelapa & $200 \mathrm{gr}$ & $200 \mathrm{gr}$ & $200 \mathrm{gr}$ \\
\hline Tepung ketan & $60 \mathrm{gr}$ & $70 \mathrm{gr}$ & $80 \mathrm{gr}$ \\
\hline Tepung wortel & $40 \mathrm{gr}$ & $30 \mathrm{gr}$ & $20 \mathrm{gr}$ \\
\hline
\end{tabular}


Tabel 1. Kadar Air dan Karoten tepung ketan, bubur wortel, dan tepung wortel

\begin{tabular}{cccc}
\hline \hline Komponen & Tepung beras ketan & Bubur wortel & Tepung wortel \\
\hline Kadar Air $(\%)(\mathrm{wb})$ & 14,12 & 90,79 & 8,60 \\
Karoten $(\mu \mathrm{g} / \mathrm{g})$ & - & 175,03 & 1627,19 \\
\hline
\end{tabular}

Keterangan: Angka dalam tabel merupakan rata - rata dari 3 kali ulangan analisa

Tabel 2. Nilai Kadar Air Dodol

\begin{tabular}{ccccc}
\hline \hline & \multicolumn{4}{c}{ Kadar Air (\%) } \\
\cline { 2 - 5 } Bentuk Substitusi & \multicolumn{3}{c}{ Konsentrasi Wortel dan Tepung Beras Ketan } \\
\cline { 2 - 5 } & $0: 100$ & $20: 80$ & $30: 70$ & $40: 60$ \\
\hline Tepung ketan (kontrol) & $16,76^{\mathrm{bc}}$ & - & - & - \\
Bubur wortel & - & $16,54^{\mathrm{abc}}$ & $17,57^{\mathrm{c}}$ & $19,90^{\mathrm{d}}$ \\
Tepung wortel & - & $16,42^{\mathrm{ab}}$ & $16,13^{\mathrm{ab}}$ & $15,59^{\mathrm{a}}$ \\
\hline \hline
\end{tabular}

Ket: Angka yang diikuti oleh huruf yang sama berarti tidak berbeda nyata pada tingkat kepercayaan $95 \%$

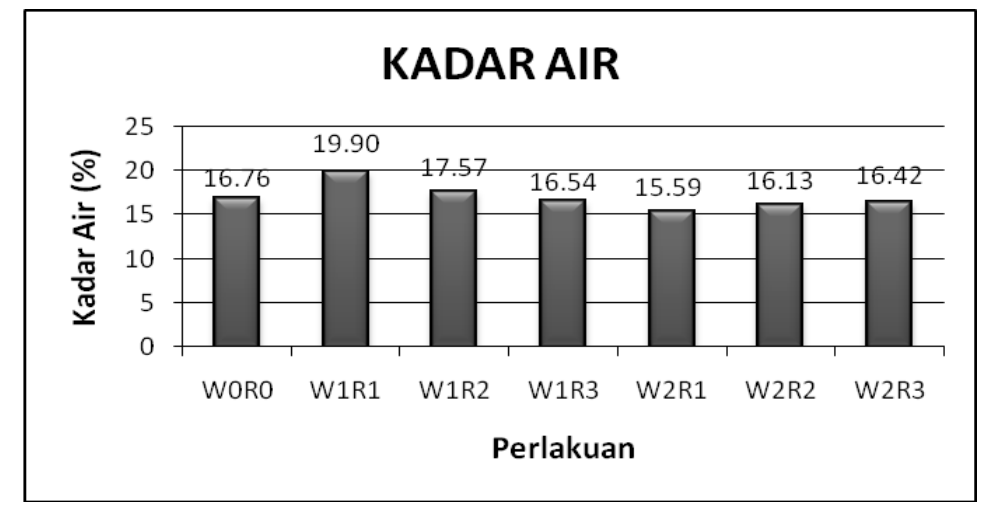

Ket sampel:

W0R0 : $100 \%$ Tepung ketan (kontrol)

W1R1 : Bubur wortel $40 \%+$ Tepung ketan $60 \%$

W1R2 : Bubur wortel 30\% + Tepung ketan $70 \%$

W1R3 : Bubur wortel $20 \%+$ Tepung ketan $80 \%$

\begin{abstract}
W2R1 : Tepung wortel $40 \%+$ Tepung ketan $60 \%$ W2R2 : Tepung wortel $30 \%+$ Tepung ketan $70 \%$ W2R3 : Tepung wortel $20 \%$ + Tepung ketan $80 \%$
\end{abstract}

\section{Pengujian Thermogravimetri 1992)}

Kadar air dihitung dengan rumus:

$$
\text { Kadar air }=\frac{\text { berat air }}{\text { berat sampel }} \times 100 \%
$$

\section{Pengujian Karoten Metode Carr Price (Gardjito dkk, 2003)}

Karoten $\left(\frac{\mu g k a r o t e n}{100 g}\right)=\frac{\text { x. Fp. } 100}{\text { Berat sampel }}$

Ket: $\mathrm{x}=$ konsentrasi karoten yang terbaca dari kurva standar $\mathrm{fp}=$ faktor pengenceran

\section{Pengujian Tekstur}

Tekstur dodol diukur dengan alat "Lloyd" Testing Machine.. Urutan kerjanya sebagai berikut : bahan diletakkan di atas plate yang disediakan, kemudian pungler diatur hingga tepat menyentuh permukaan bahan. Alat mulai dijalankan dan komputer akan mencetak kekuatan bahan dengan membentuk kurva.

\section{Pengujian Organoleptik}

Pengujian sensoris dodol meliputi warna, aroma, cita rasa, tekstur dan keseluruhan. Pengujian dilakukan berdasar kesukaan dengan metode Scale Hedonic Test. Skala penilaiannya ialah bertahap dari nilai 1 (=suka) sampai 5 (=tidak suka), dilakukan oleh 20 orang penguji sensoris. 
Tabel 3. Nilai Karoten Dodol

\begin{tabular}{ccccc}
\hline \hline \multirow{2}{*}{ Bentuk Substitusi } & \multicolumn{4}{c}{ Karoten $(\mu \mathrm{g} / \mathrm{g})$} \\
\cline { 2 - 5 } & $0: 100$ & $20: 80$ & $30: 70$ & $40: 60$ \\
\cline { 2 - 5 } Kepung ketan (kontrol) & $1,04^{\mathrm{a}}$ & - & - & - \\
Bubur wortel & - & $5,36^{\mathrm{ab}}$ & $9,26^{\mathrm{b}}$ & $11,04^{\mathrm{b}}$ \\
& - & $89,56^{\mathrm{c}}$ & $117,94^{\mathrm{d}}$ & $177,18^{\mathrm{e}}$ \\
\hline \hline
\end{tabular}

Ket: Angka yang diikuti oleh huruf yang sama berarti tidak berbeda nyata pada tingkat kepercayaan $95 \%$

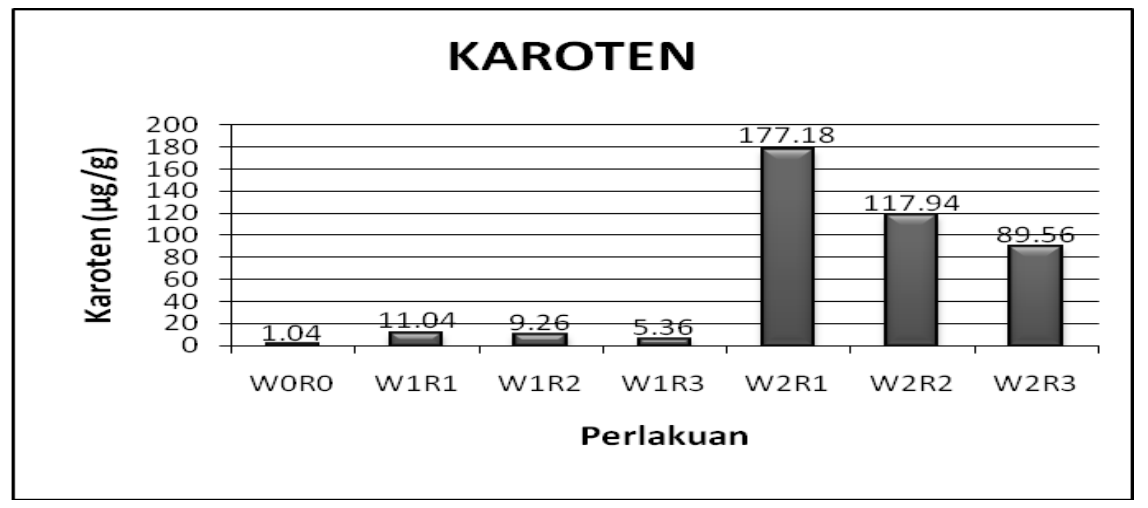

Gambar 3. Grafik Karoten Dodol

Rancangan percobaan yang digunakan dalam penelitian ini adalah Rancangan Acak Lengkap Faktorial dengan 2 variabel yaitu variabel tetap dan variabel tidak tetap. Variabel tetap yaitu variasi bentuk penambahan wortel (bubur wortel dan tepung wortel) dan variasi konsentrasi wortel dan tepung beras ketan yaitu 40:60, 30:70, 20:80, dan 0:100 (kontrol), sedangkan variabel tidak tetap yaitu kadar air, kadar karoten, tekstur, dan sifat sensoris. Percobaan dilakukan dengan tiga kali ulangan. Data yang diperoleh dianalisa dengan Univariate, dan untuk mengetahui perbedaan antara perlakuan digunakan uji DMRT (Duncan's Multiple Range Test) dengan taraf nyata $5 \%$.

\section{HASIL DAN PEMBAHASAN}

Berdasarkan penelitian didapat, Kadar air dan Karoten Tepung Beras Ketan, Bubur Wortel, dan Tepung Wortel Seperti Tabel 1.

Pada penelitian ini, karoten bubur wortel adalah 175,03 $\mu \mathrm{g} / \mathrm{g}$, sedangkan karoten tepung wortel $1627,19 \mu \mathrm{g} / \mathrm{g}$. Menurut Herastuti (1981), bahan yang sudah ditepungkan akan memiliki tingkat kelarutan dalam suatu pelarut yang lebih tinggi dibandingkan bahan yang belum ditepungkan, sehingga dalam penelitian ini karoten pada tepung wortel lebih mudah terekstrak dan larut dalam pelarut petroleum eter dibandingkan karoten dalam bubur wortel.

\section{Komposisi Kimia dan Sifat Fisik Dodol}

\section{Kadar Air}

Kadar air merupakan salah satu parameter mutu dodol yang sangat penting, karena dodol merupakan jenis produk pangan semi basah sehingga kadar air akan sangat mempengaruhi umur simpannya. Kadar air dodol yang dihasilkan pada penelitian ini dapat dilihat pada Tabel 2 dan Gambar 2.

Berdasarkan hasil analisa kadar air dodol, konsentrasi bubur wortel dan tepung ketan 30:70, 20:80, dan dodol dengan konsentrasi tepung wortel dan tepung ketan 30:70, 20:80 kadar sebesar 16,13 sampai $16,76 \%$. Namun kadar air dodol dengan konsentrasi bubur wortel: ketan 40:60 dan dodol dengan konsentrasi tepung wortel : tepung ketan 40:60 berbeda nyata dengan kadar air dodol kontrol yaitu sebesar 19,90 dan 15,59\%.

Berdasarkan SNI 01-2986-1992, produk dodol disyaratkan mempunyai kadar air maksimal 20\%. Sehingga kadar 
Tabel 4. Tingkat Kekerasan Dodol

\begin{tabular}{ccccc}
\hline \hline \multirow{2}{*}{ Bentuk Substitusi } & \multicolumn{4}{c}{ Gaya Tekan (N) } \\
\cline { 2 - 5 } & $0: 100$ & $20: 80$ & $30: 70$ & $40: 60$ \\
\cline { 2 - 5 } & $4,19^{\mathrm{a}}$ & - & - & - \\
\hline Tepung ketan (kontrol) & - & $4,92^{\mathrm{ab}}$ & $2,24^{\mathrm{a}}$ & $2,18^{\mathrm{a}}$ \\
Bubur wortel & - & $7,69^{\mathrm{abc}}$ & $12,07^{\mathrm{bc}}$ & $14,39^{\mathrm{c}}$ \\
\hline \hline
\end{tabular}

Ket: Angka yang diikuti oleh huruf yang sama berarti tidak berbeda nyata pada tingkat kepercayaan $95 \%$

Tabel 5. Elastisitas Dodol

\begin{tabular}{ccccc}
\hline \hline \multirow{2}{*}{ Bentuk Substitusi } & \multicolumn{4}{c}{$\varepsilon$ Fmax (mm) } \\
\cline { 2 - 5 } & $0: 100$ & $20: 80$ & $30: 70$ & $40: 60$ \\
\cline { 2 - 5 } & $8.09^{\mathrm{b}}$ & - & - & - \\
\hline Tepung ketan (kontrol) & - & $8.88^{\mathrm{b}}$ & $6.16^{\mathrm{a}}$ & $6.18^{\mathrm{a}}$ \\
Bubur wortel & - & $8.73^{\mathrm{b}}$ & $7.95^{\mathrm{b}}$ & $7.60^{\mathrm{b}}$ \\
\hline \hline
\end{tabular}

Ket: Angka yang diikuti oleh huruf yang sama berarti tidak berbeda nyata pada tingkat kepercayaan $95 \%$

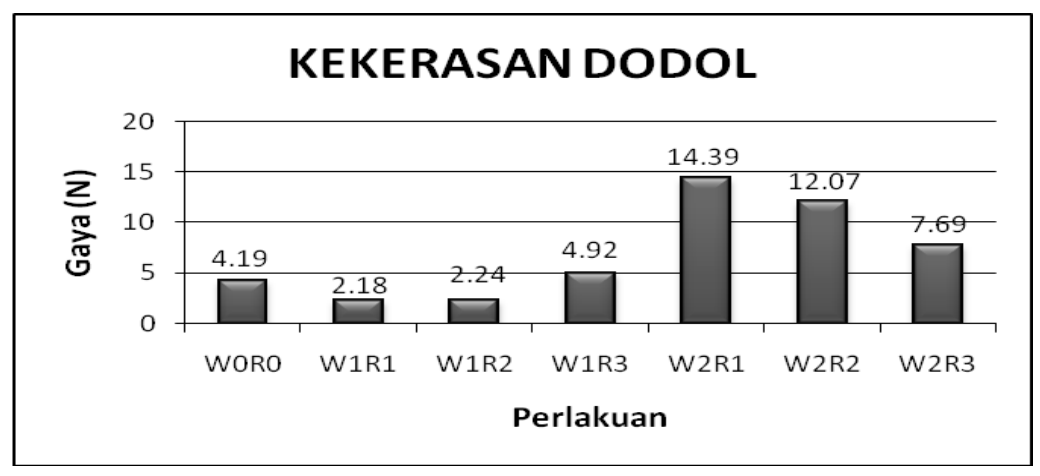

Gambar 4. Grafik Kekerasan Dodol

air dodol yang dihasilkan dalam penelitian ini antara $15,59-19,90 \%$, sudah memenuhi SNI yang ada.

\section{Kadar Karoten Dodol Wortel}

Pada pembuatan dodol wortel, kerusakan karoten oleh pemanasan pada suhu tinggi $\left( \pm 95^{\circ} \mathrm{C}\right)$ dan dalam kondisi terbuka sehingga memungkinkan terjadi oksidasi karotenoid. Menurut Rustishausher (1992), karoten stabil pada pemanasan tidak lebih dari $100{ }^{\circ} \mathrm{C}$. Hasil analisa karoten dodol wortel disajikan pada Tabel 3 dan Gambar 3.

Berdasarkan Tabel 3 diketahui bahwa dodol kontrol mengandung karoten sebesar 1,04 $\mu \mathrm{g} / \mathrm{g}$, sedangkan dodol dengan penambahan bubur wortel mengandung karoten sebesar 5,36 sampai $11,04 \mu \mathrm{g} / \mathrm{g}$ dan dodol dengan penambahan tepung wortel mengandung karoten sebesar 89,56 sampai 177,18 $\mu \mathrm{g} / \mathrm{g}$. Penambahan wortel baik dalam bentuk bubur maupun tepung wortel dengan perbedaan konsentrasi wortel dan tepung ketan secara statistik memberikan pengaruh yang beda nyata terhadap kadar karoten dodol, karena wortel dapat meningkatkan kandungan karoten pada dodol.

\section{Tekstur Dodol}

Tekstur merupakan atribut bahan sebagai akibat perpaduan sifat - sifat fisik yang meliputi bentuk, ukuran, warna, dan unsur - unsur pembentuk struktur bahan yang dapat dirasakan oleh indra peraba (mounth feel dan finger feel), indra penglihatan dan indra pendengar. (Matz, 


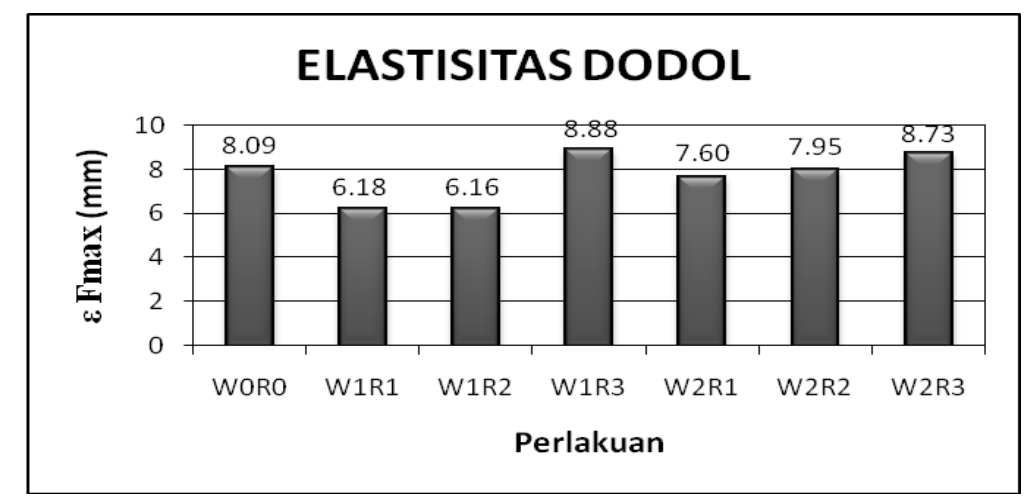

Gambar 5. Grafik Elastisitas Dodol

Tabel 6. Hasil Uji Organoleptik Dodol

\begin{tabular}{|c|c|c|c|c|c|}
\hline \hline \multirow{2}{*}{ Sampel } & \multicolumn{5}{|c|}{ Parameter } \\
\cline { 2 - 6 } & Warna & Aroma & Rasa & Tekstur & Keseluruhan \\
\hline W0R0 & $2,75^{\mathrm{a}}$ & $2,05^{\mathrm{ab}}$ & $2,30^{\mathrm{a}}$ & $3,25^{\mathrm{a}}$ & $2,60^{\mathrm{a}}$ \\
W1R1 & $2,30^{\mathrm{a}}$ & $2,15^{\mathrm{abc}}$ & $2,35^{\mathrm{a}}$ & $4,00^{\mathrm{b}}$ & $3,10^{\mathrm{a}}$ \\
W1R2 & $2,45^{\mathrm{a}}$ & $1,75^{\mathrm{a}}$ & $2,10^{\mathrm{a}}$ & $2,95^{\mathrm{a}}$ & $2,50^{\mathrm{a}}$ \\
W1R3 & $2,50^{\mathrm{a}}$ & $2,45^{\mathrm{abc}}$ & $2,45^{\mathrm{a}}$ & $2,80^{\mathrm{a}}$ & $2,75^{\mathrm{a}}$ \\
W2R1 & $2,30^{\mathrm{a}}$ & $2,85^{\mathrm{c}}$ & $3,25^{\mathrm{b}}$ & $3,10^{\mathrm{a}}$ & $3,15^{\mathrm{a}}$ \\
W2R2 & $2,05^{\mathrm{a}}$ & $2,60^{\mathrm{bc}}$ & $2,85^{\mathrm{ab}}$ & $2,70^{\mathrm{a}}$ & $2,70^{\mathrm{a}}$ \\
W2R3 & $2,10^{\mathrm{a}}$ & $2,35^{\mathrm{abc}}$ & $2,50^{\mathrm{a}}$ & $2,50^{\mathrm{a}}$ & $2,65^{\mathrm{a}}$ \\
\hline \hline
\end{tabular}

Ket: Angka yang diikuti oleh huruf yang sama pada kolom yang sama berarti tidak berbeda nyata pada tingkat kepercayaan $95 \%$

Nilai lebih kecil berarti lebih disukai

Ket sampel:

W0R0 : $100 \%$ Tepung ketan (kontrol)

W1R1 : Bubur wortel $40 \%+$ Tepung ketan $60 \%$

W1R2 : Bubur wortel 30\% + Tepung ketan $70 \%$

W1R3 : Bubur wortel 20\% + Tepung ketan $80 \%$

1962). Sedangkan kekerasan menurut Timorsih (2006), merupakan respon bahan terhadap penekanan dengan beban tertentu sampai terjadi deformasi bahan. Sedangkan Elastisitas menggambarkan reaksi bahan tersebut apabila dikenai gaya (aksi). Hasil analisa tekstur dodol (tingkat kekerasan dan elastisitas) seperti pada Tabel 4 dan Tabel 5.

Dari Tabel 4 dapat dilihat bahwa perbedaan wortel yang ditambahkan dalam bentuk bubur maupun tepung wortel berpengaruh terhadap tingkat kekerasan dodol, dodol dengan penambahan tepung wortel memiliki tingkat kekerasan yang lebih tinggi daripada dodol bubur wortel.

Semakin tinggi kadar air suatu bahan makanan maka teksturnya akan semakin lunak (Matz, 1962). Bubur wortel yang digunakan pada penelitian ini
W2R1 : Tepung wortel $40 \%+$ Tepung ketan $60 \%$ W2R2 : Tepung wortel $30 \%+$ Tepung ketan $70 \%$ W2R3 : Tepung wortel 20\% + Tepung ketan $80 \%$

mempunyai kadar air yang lebih tinggi dari pada tepung wortel, sehingga semakin tinggi konsentrasi bubur wortel pada dodol maka semakin rendah tingkat kekerasannya.

Berdasarkan Tabel 5 diketahui bahwa tingkat elastisitas dodol dengan penambahan bubur wortel (bubur wortel : tepung ketan, 40:60, 30:70), serta dodol dengan penambahan tepung wortel (tepung wortel : tepung ketan, 40:60, 30:70) memiliki tingkat elastisitas rendah.

\section{Sifat Organoleptik Dodol}

Analisa sifat organoleptik untuk mengetahui sejauh mana penerimaan panelis terhadap produk dodol wortel. Pada penelitian ini maka digunakan uji kesukaan (Hedonic Test) dengan menggunakan skala 1 (= suka), 2 (= agak suka), 3 (= netral), 4 (= agak tidak suka) 
dan 5 (= tidak suka). Hasil pengujian organoleptik dodol dapat dilihat pada Tabel 6.

\section{Warna}

Dari Tabel 6 menunjukkan bahwa nilai rata - rata kesukaan panelis terhadap warna dodol wortel berkisar antara 2,05 sampai 2,75. Hal ini berarti bahwa penilaian panelis terhadap kesukaan warna dodol yang dihasilkan adalah agak suka sampai netral (biasa).

\section{Aroma}

Tabel 6 menunjukkan bahwa nilai rata rata kesukaan panelis terhadap atribut aroma dodol berkisar antara 1,75 sampai 2,85. Hal ini berarti secara umum penilaian panelis bersifat agak suka sampai netral (biasa).

\section{Rasa}

Pada Tabel 6 menunjukkan nilai rata rata tingkat kesukaan panelis terhadap atribut rasa dodol berkisar antara 2,10 sampai 3,25. Hal ini berarti tingkat penerimaan panelis terhadap atribut rasa antara agak suka sampai netral

\section{KESIMPULAN}

1. Wortel yang disubstitusikan dalam dodol bentuk bubur maupun tepung, dengan perbedaan konsentrasi wortel dan tepung beras ketan berpengaruh terhadap kadar air, karoten dan tekstur dodol yang dihasilkan yaitu bubur wortel : tepung ketan, 20:80, 30:70, 40:60) memiliki kadar air sebesar 16,54\%, 17,57\%, $19,90 \%$, mengandung karoten sebesar $5,36 \mu \mathrm{g} / \mathrm{g}, 9,26 \mu \mathrm{g} / \mathrm{g}, 11,04 \mu \mathrm{g} / \mathrm{g}$,

2. Tingkat kekerasan yang dinyatakan dengan gaya tekan sebesar 4,92 N; 2,24 $\mathrm{N} ; 2,18 \mathrm{~N}$ serta tingkat elastisitas yang dinyatakan dengan $\varepsilon$ Fmax sebesar 8,88 $\mathrm{mm} ; 6.16 \mathrm{~mm} ; 6,18 \mathrm{~mm}$.. Sedangkan dodol dengan penambahan tepung wortel (tepung wortel : tepung ketan, 20:80, 30:70, 40:60) memiliki kadar air sebesar $16,42 \%, 16,13 \%, 15,59 \%$, mengandung karoten sebesar 89,56 $\mu \mathrm{g} / \mathrm{g}, 117,94 \mu \mathrm{g} / \mathrm{g}$, $177,18 \mu \mathrm{g} / \mathrm{g}$, dan memiliki tingkat kekerasan yang dinyatakan dengan gaya tekan sebesar 7,69 N; 12,07 N; 14,39 N serta tingkat elastisitas yang dinyatakan dengan $\varepsilon$ Fmax sebesar $8,73 \mathrm{~mm} ; 7,95$ $\mathrm{mm} ; 7,60 \mathrm{~mm}$.

3. Secara keseluruhan dodol yang disukai pada penelitian ini adalah dodol dengan penambahan bubur wortel dengan konsentrasi bubur wortel dan tepung beras ketan 30:70

\section{DAFTAR PUSTAKA}

Ali, Nur Berlian Venus dan Estu Rahayu. 1994. Wortel dan Lobak. Penebar Swadaya. Jakarta.

Anonim. 2008. SPO Dodol. agribisnis.deptan.go.id. Diakses pada Hari Selasa 25 Maret 2008. Pukul 11.00.

Asih - Nurhayati, 1999. Penggantian Santan dengan Beberapa Bahan Mengandung Lemak, Protein dan Air dalam Pembuatan Dodol yang Diolah dengan Tekanan Tinggi. Fakultas Teknologi Pertanian UGM, Yogyakarta.

DeMan, J. M., 1999. Principle of Food Chemistry. Third Edition. Aspen Publishers, Inc. Gaithersburg, Maryland. Dalam Budarti Timorsih. 2006. Pengaruh Rasio Beras Ketan dan Labu Kuning (Curcubita sp.) pada Pembuatan Dodol. Skripsi. UGM. Yogyakarta.

Haryadi. 1998. Modifikasi Proses Pembuatan Dodol. Jurnal Agritech Vol. 18, Hal. 29 - 30.

Herastuti,S.R. 1981. Stabilitas Provitamin A dan Warna dalam Pembuatan Tepung Wortel (Daucus carota). Thesis. IPB. Bogor.

Karrer, P. and E. A. Jucker. 1950. Carotenoid. Elvevier Publishing Company. New York. Dalam Theresia Fitria K.S. 2006. Pengaruh Penambahan Asam Sitrat Dalam Pembuatan Manisan Kering Labu Kuning (Curcubita maxima) Terhadao Sifat - Sifat Produknya. Skripsi. UGM. Yogyakarta.

Kartika, Bambang, Pudji Hastuti, dan Wahyu Supartono. 1988. Pedoman Uji Inderawi Bahan Pangan. PAU Pangan dan Gizi Universitas Gadjah Mada. Yogyakarta

Lewis, M.J. 1987. Physical Properties of Foods and Food Processing System. Cametot Press. Canada. 
Matz, S. A., 1962. Water in Food. The AVI Publishing Company Inc., Westport, Connecticut.

Murdijati Gardjito, Agnes Murdiarti dan Zuheid Noor. 1989. Produk Campuran Tepung kaya Vitamin A dan Kajian Sifat - Sifatnya. Laporan Penelitian FTP. UGM. Yogyakarta.

Murdijati Gardjito, Agung Setya Wardana. 2003. Hortikultura Teknik Analisis Pasca Panen. Transmedia Mitra Printika. Yogyakarta. 